\title{
Analysis of Argumentation Skills in Biology Learning at Surakarta Senior High School
}

\author{
R Purwati ${ }^{1}$, Suranto ${ }^{2}$, Sajidan $^{3}$, N M Prasetyanti ${ }^{4}$ \\ ${ }_{1,2,3}$ Universitas Sebelas Maret \\ ${ }^{4}$ SMA Negeri 3 Surakarta \\ \{ranipurwati10@gmail.com¹, surantoak@yahoo.com², sajidan@fkip.uns.ac.id³, \\ nanikmpsolo@gmail.com ${ }^{4}$ \}
}

\begin{abstract}
Argumentation skill is essential academic skills in comprehensive learning in the 21 st century for developing, evaluating and validating knowledge. Argumentation skills are ability to criticize an idea or information so that the information was obtained correctly by connecting data and information to produce strong and precise ideas. This research aimed to analyze argumentation skills of students at Surakarta Senior High School in biology learning. The research subjects were the twelfth-grade students of public senior high schools in Surakarta. The data collection was conducted online with Edmodo media. The results showed that $17.8 \%$ were still at level one, where the arguments issued by students only contained a simple claim, and for the level two $3.3 \%$ were in which the arguments issued by students were supported by data without warranting and backing document. The results of the initial ability test showed that the rebuttal aspect had not developed. The result indicates that the students' argumentation skills in Surakarta Senior High School were still quite low.
\end{abstract}

Keywords: Argumentation Skills, Learning Biology.

\section{INTRODUCTION}

The need of skill in the $21^{\text {st }}$ century have changed from acquiring structured knowledge to skills mastery [1]. These skills include collaborative skills, communication skills [2], analytical thinking skills, critical thinking skills and argumentation skills [3]. Argumentation skills which is define as the ability to criticize an idea or information so that information is obtained correctly [4], and this could be found by connecting data and information to produce valid, strong and precise ideas [5].

Argumentation skills are very much needed especially in evaluating logically arising issues [6] and justifying decisions in both written and oral formats [7]. This skills can empower students' communication skills that can be used in everyday life. The adequacy of good argumentation skills allows to make decisions and solve the problems, especially complex problems which arose in human daily life.

Aspects of argumentation skills according consist of six aspects, namely claim, data, warrant, backing, qualifier, and rebuttal [8]. Claim is a topical affirmation that is being studied. Data is a statement that is used as evidence to support claims. Warrant is a statement that explains the relationship between data and claims. Backing is a statement used to 
strengthen a warrant. A qualifier is a statement that gives rise to the power of data that supports claims [9].

The quality of an argument or the weakness of an argument is determined by understanding the concept supported by data or evidence, an explanation that contains the reasons, and how to build these components so that they are convincing. Assessment of the teacher's argumentation skills can provide a variety of questions and students answer the question.

\subsection{Research Method}

This research is quantitative using the written test scores of the students as the data. They were analyzed to find out the argumentation skills in every aspect. 75 twelfth-grade science students of public senior high schools in Surakarta of the fifth semester became the subject of this research. They were divided into 3 classes with 25 female and male students, respectively. The data were collected online by using Edmodo media using short questions accompanied by reasons. The short question consisted of 3 questions. Quantitative and qualitative methods were applied during data analyses. The scores were categorized according the each aspect. They were then made into 5 categories of decisions as shown in the following table.

Table 1. Argumentation skill categories in four different levels [10].

\begin{tabular}{lll}
\hline \multicolumn{1}{c}{$\begin{array}{c}\text { Level of } \\
\text { Argumentation }\end{array}$} & \multicolumn{1}{c}{ Argument Structure } \\
\hline Level 1 & $:$ & Arguments that contain a simple claim. \\
Level 2 & $:$ & $\begin{array}{l}\text { Arguments consisting of claim and data. } \\
\text { Level } 3\end{array}$ \\
Level 4 & $:$ & $\begin{array}{l}\text { Arguments consisting of claims with data, warrants, or backings, but } \\
\text { do not contain any rebuttals. }\end{array}$ \\
\hline
\end{tabular}

\subsection{Result and Discussion}

The result of the research showed students' argumentation skills in Biology learning in Surakarta Public Senior High School using short-question written test as the instrument is as follows:

Table 2. Result of argumentation skills analysis in four different levels.

\begin{tabular}{ccc}
\hline $\begin{array}{c}\text { Level of } \\
\text { Argumentation }\end{array}$ & Percentage \\
\hline Level 1 & $:$ & $17,8 \%$ \\
Level 2 & $:$ & $3,3 \%$ \\
Level 3 & $:$ & $0 \%$ \\
Level 4 & $:$ & $0 \%$ \\
\hline
\end{tabular}

The results of the argumentation skills test in collecting data argumentation skills of students as much as $17.8 \%$ are still at level one, in which the arguments issued by students only contain simple claims, $3.3 \%$ are at level two where arguments issued by students are supported by data without warranting warrant and backing. The results of the analysis show 
that the rebuttal aspect has not developed. Rebuttal is an essential aspect in argumentation skill [11].

The ability to argue is able to increase the potential possessed by students. The development of arguments in learning can support several advantages, including the development of cognitive and student metacognitive processes, developing competencies in communication and critical thinking, achieving scientific literacy in students and empowering students to speak and write scientifically and support development of student reasoning.

A bad argument is caused by students not knowing the components of the argument. Good argumentation describes the process of thinking and social interaction that builds and evaluates individual arguments [12]. Students often do not include aspects of argumentation in full (statement, reason, evidence) or do not mention clearly, the evidence used is sometimes not able to be developed, students also sometimes do not respond to other alternative views. A good argument is an argument that contains a statement accompanied by evidence and reasons that link the statement with evidence.

The results of the initial ability test showed that the rebuttal aspect had not developed. It means that science learning needs to be changed. Empowerment of argumentation skills must be integrated in the learning system in the classroom [13]. Argumentation skills are empowered by: (1) Establishing daily life problems that are appropriate for learning content [14]; (2) Debates related to problems raised in learning; (3) Present questions according to learning content. Problems encountered in learning are problems that have several alternative solutions [15] and raise many perspectives which trigger debate [16]. During learning students are asked to identify problems and provide critical judgments by giving claims that are supported by data and rebuttal to reject a claim against problems raised.

Debates related to problems or issues and cases in everyday life taken from mass media advertisements, scenarios, and government speeches [17] that are in line with learning content that stimulates students to understand content well to maintain claims given. Argumentation skills can be introduced in science classrooms by facilitating student discourse through Socratic questioning, conceptual questions, open-ended questions, multiple choices are accompanied by reasons or short questions that require students to give reasons to stimulate the development of argumentation skills [18].

Question and answer and debate methods are considered effective in stimulating students' argumentation skills [19]. The Socratic Question and Answer Method is a popular approach in teaching. This method applies a form of investigation with open discussion where individual perspective is compared to the other. Learning is done through investigating and thinking about the questions as to stimulate the students' original thinking. The benefit of the Socrates method is that students get to know their gaps of knowledge, encouraging them to clarify ideas and understand the concept better.

Conceptual questions are used to help students begin the process of problem-solving while guiding students to master important concepts in the subjects taught [20]. Open-ended questions allow students to interact dialogically with peers to build, criticize, and perfect understanding of scientific phenomena [21] Open-ended questions are a feature of problembased learning that is retained as a learning stimulus. Open-ended is intended to improve the ability of students to argue, one way is to observe how students use the knowledge that has been learned and then applied in everyday life that is contextual in nature. Open-ended questions force students to find a solution positively, with the existence of several answers and ways of solving obtained from joint activities that he himself did is a posited experience that will increase students' insight into diversity, especially in dealing with similar problems. Open 
questions have keywords discussed, interpreted, explained, evaluated, compared, if or what. The types of questions that can empower argumentation skills are shown in Table 3.

Table 3. Question Types which could Empower Argumentation Skills of Student [22].

\begin{tabular}{|c|c|c|}
\hline $\begin{array}{c}\text { Question } \\
\text { Type }\end{array}$ & Description & Sample question \\
\hline Divergent & $\begin{array}{l}\text { Open, has many } \\
\text { responses; enabling } \\
\text { exploration of diverse } \\
\text { perspectives; encourage } \\
\text { dialogue. }\end{array}$ & $\begin{array}{l}\text { There are several regions that do not allow } \\
\text { GMO products to be marketed. Why? }\end{array}$ \\
\hline Focal & $\begin{array}{l}\text { Students must choose } \\
\text { or justify a position. }\end{array}$ & $\begin{array}{l}\text { Today's development of Molecular Biology } \\
\text { encourages major findings for human life, such } \\
\text { as cloning, IVF and other forms of genetic } \\
\text { engineering. Various debates then arose and } \\
\text { were voiced as a form of protest because these } \\
\text { efforts actually violated human ethics and } \\
\text { damaged the order of life that was actually } \\
\text { perfect. What is your position as a biologist } \\
\text { about that? If you agree, why? If not, why? }\end{array}$ \\
\hline Brainstorm & $\begin{array}{l}\text { Questions that generate } \\
\text { a list of ideas or points } \\
\text { of view. }\end{array}$ & $\begin{array}{l}\text { If you can create ideal molecular biology } \\
\text { products, products that can be widely used, } \\
\text { what will you make? }\end{array}$ \\
\hline
\end{tabular}

\section{CONCLUSIONS}

Argumentation skills of the twelfth-grade science students of public senior high schools in Surakarta have not yet been optimized as evidenced by reviewing the aspects of argumentation skills that $17.8 \%$ were still at level one where the arguments issued by students only contained a simple claim, 3.3\% were at level two where arguments issued by students were supported by data without warranting and backing. The results of the initial ability test showed that the rebuttal aspect had not developed. The results indicate the low argumentation skills of the students in Surakarta Senior High Schools. It is suggested that the teacher improve the students' argumentation skills with a learning model that trains their high-order thinking skills, which reflect their skills through the learning process.

\section{ACKNOWLEDGMENT}

The author expresses her gratitude the Beasiswa Prestasi Universitas Sebelas Maret for providing education funding. 


\section{REFERENCES}

[1] F. van As, "An exploratory evaluation of a South African project-based curriculum module focused on authentic technological practice utilizing student portfolios and an open-ended questionnaire," Int. J. Technol. Des. Educ., pp. 1-15, 2018.

[2] Y. Chung, J. Yoo, S.-W. Kim, H. Lee, and D. L. Zeidler, "Enhancing Students' Communication Skills in the Science Classroom Through Socioscientific Issues," Int. J. Sci. Math. Educ., no. 2016, pp. 1-27, 2014.

[3] J. yoon Jang and B. Hand, "Examining the Value of a Scaffolded Critique Framework to Promote Argumentative and Explanatory Writings Within an Argument-Based Inquiry Approach,” Res. Sci. Educ., vol. 47, no. 6, pp. 1213-1231, 2017.

[4] Y. C. Chen, B. Hand, and S. Park, "Examining Elementary Students' Development of Oral and Written Argumentation Practices Through Argument-Based Inquiry," Sci. Educ., vol. 25, no. 3-4, pp. 277-320, 2016.

[5] P. S. Cetin, N. Dogan, and A. Y. Kutluca, "The Quality of Pre-service Science Teachers' Argumentation: Influence of Content Knowledge,” J. Sci. Teacher Educ., vol. 25, no. 3, pp. 309-331, 2014.

[6] P. Fettahlığlu, "Developing Environmentally Responsible Behaviours Through the Implementation of Argumentation- and Problem-Based Learning Models," 2018.

[7] V. Dawson and K. Carson, "Introducing Argumentation About Climate Change Socioscientific Issues in a Disadvantaged School," 2018.

[8] S. E. Toulmin, The uses of argument: Updated edition. 2003.

[9] A. A. Tawfik, "Do cases teach themselves? A comparison of case library prompts in supporting problem-solving during argumentation," J. Comput. High. Educ., vol. 29, no. 2, pp. 267-285, 2017.

[10] M. Garcia-Mila, S. Gilabert, S. Erduran, and M. Felton, "The Effect of Argumentative Task Goal on the Quality of Argumentative Discourse," Sci. Educ., vol. 97, no. 4, pp. 497-523, 2013.

[11] A. Crowell and D. Kuhn, "Developing Dialogic Argumentation Skills: A 3-year Intervention Study," J. Cogn. Dev., vol. 15, no. 2, pp. 363-381, 2014.

[12] P. Potter and B. France, "Informing a pedagogy for design and problem-solving in hard materials by theorising technologists' learning experiences," Int. J. Technol. Des. Educ., vol. 28 , no. 1 , pp. 101-120, 2018.

[13] N. Akben, "Effects of the Problem-Posing Approach on Students ' Problem Solving Skills and Metacognitive Awareness in Science Education," 2018.

[14] A. A. Tawfik, H. Alhoori, C. W. Keene, C. Bailey, and M. Hogan, "Using a Recommendation System to Support Problem Solving and Case-Based Reasoning Retrieval," Technol. Knowl. Learn., vol. 23, no. 1, pp. 177-187, 2018.

[15] S. S. Lin, "Science and non-science undergraduate students' critical thinking and argumentation performance in reading a science news report," Int. J. Sci. Math. Educ., vol. 12, no. 5, pp. 1023-1046, 2014.

[16] D. J. Boerwinkel, A. Yarden, and A. J. Waarlo, "Reaching a Consensus on the Definition of Genetic Literacy that Is Required from a Twenty-First-Century Citizen," Sci. Educ., vol. 26, no. 10, pp. 1087-1114, 2017.

[17] J. S. B. T. Evans and K. E. Stanovich, "Dual-Process Theories of Higher Cognition: Advancing the Debate," Perspect. Psychol. Sci., vol. 8, no. 3, pp. 223-241, 2013.

[18] S. M. Brookhart, Assess HOTS In Your Classroom. 2007.

[19] K. Iordanou and C. P. Constantinou, “Developing pre-service teachers' evidence-based 
argumentation skills on socio-scientific issues," Learn. Instr., vol. 34, pp. 42-57, 2014.

[20] K. Saddhono and M. Rohmadi, "A Sociolinguistics Study on the Use of the Javanese Language in the Learning Process in Primary Schools in Surakarta, Central Java, Indonesia." Int. Edu. Stu., vol. 7 no.6 pp 25-30, 2014

[21] N. Eliasson, K. G. Karlsson, and H. Sørensen, "The role of questions in the science classroom-how girls and boys respond to teachers' questions*," Int. J. Sci. Educ., vol. 39, no. 4, pp. 433-452, 2017.

[21] T. Tofade, J. Elsner, and S. T. Haines, "Best practice strategies for effective use of questions as a teaching tool," Am. J. Pharm. Educ., vol. 77, no. 7, 2013. 